\title{
STRATEGI REFLEKTIF DAN TRANSINTERNAL SEBAGAI UPAYA MENUMBUHKAN PENGHAYATAN SISWA DALAM PEMBELAJARAN PAI
}

\author{
ASNAH \\ Dosen Fakultas Tarbiyah dan Ilmu Keguruan IAIN Padangsidimpuan \\ Email: asnahray@gmail.com
}

\begin{abstract}
Teaching PAI has been started from Elementary School until Senior High School, or even for University students; it was generally cognitive oriented. The students asked to know the Islamic teaching, not to comprehend or to implement; they only know and not try to implement the teaching. In order to resolve it, the researcher tried to suggest one affective oriented strategy, it is the reflective and transinternal teaching strategy. It has been done for the grade X-5 SMA N 5 Padangsidimpuan with the total participants are 39 students Moslem, 17 male students and 22 female students. Research has been done by palling, acting, observing and reflecting the action. The data collection are students' attitude, rational thinking, wider knowledge, feeling, and comprehending of the students to Islamic teaching values. The result showed that this strategy are able to develop students' mental attitude, rational thinking, knowledge, proud of Allah's power, emphatic, and to change bad attitude become a good one.
\end{abstract}

Keywords: Reflective and Transinternal strategy, Islamic teaching, and students' comprehension.

\begin{abstract}
Abstrak
Pembelajaran PAI di sekolah mulai dari tingkat sekolah dasar sampai ke tingkat lanjutan atas bahkan pembelajaran agama di perguruan tinggi, umumnya lebih berorientasi kognitif. Peserta didik lebih ditekankan untuk mengetahui ajaran agama, sementara aspek penghayatan dan keterampilan/pengamalan terabaikan. Hal ini menyebabkan peserta didik tau tapi tidak mengamalkan ajaran agama. Untuk memperbaiki kekeliruan tersebut peneliti berupaya menawarkan strategi pembelajaran yang berorientasi afektif yaitu strategi pembelajaran reflektif dan transinternal. Penelitian ini dilaksanakan di kelas X 5 SMA N 3 Padangsidimpuan dengan siswa berjumlah 39 orang yang keseluruhannya beragama Islam, 17 lakilaki dan 22 perempuan. Adapun rancangan penelitian dilakukan dengan tahapan perencanaan tindakan, pelaksanaan tindakan, observasi dan refleksi. Sedangkan jenis data yang akan dikumpulkan adalah sikap, kesadaran rasional dan keluasan wawasan siswa serta perasaan dan penghayatan siswa terhadap nilai-nilai ajaran Islam. Analisis data secara naratif dan juga menggunakan analisis statistik deskriptif dalam bentuk tabulasi frekuensi. Dalam pelaksanaannya,
\end{abstract}


strategi reflektif maupun transinternal telah berhasil menumbuhkan sikap mental, kesadaran rasional, keluasan wawasan, perasaan kagum akan kekuasaan Allah, empati terhadap sesama makhluk Allah, terdorong untuk merubah perilaku yang kurang baik dan meningkatkan perbuatan baik.

Kata Kunci: strategi reflektif dan transinternal, pembelajaran PAI, dan penghayatan siswa.

\section{PENDAHULUAN}

Pembelajaran pendidikan agama Islam yang selama ini berlangsung dirasakan kurang terkait atau kurang concern terhadap persoalan bagaimana mengubah pengetahuan agama yang bersifat kognitif menjadi makna dan nilai yang perlu diinternalisasikan dalam diri peserta didik, untuk selanjutnya menjadi sumber motivasi bagi peserta didik untuk berbuat dan berperilaku secara konkret-agamis dalam kehidupan sehari-hari.

Bila kita amati fenomena empirik yang ada di hadapan dan sekeliling kita maka tampaklah bahwa pada saat ini terdapat banyak kasus kenakalan di kalangan pelajar. Isu perkelahian pelajar, tindak kekerasan, konsumsi minuman keras, etika berlalu lintas, pergaulan bebas, kriminalitas dan sebagainya. Munculnya kasus-kasus tersebut memang tidak semata-mata karena kegagalan pendidikan agama Islam di sekolah yang lebih menekankan aspek kogitif. Akan tetapi bagaimana semua persoalan itu dapat mendorong dan menggerakkan guru agama Islam untuk mencermati kembali dan mencari solusi melalui pembelajaran pendidikan agama Islam yang berorientasi pada pendidikan nilai (afektif).

Sebagaimana diketahui bahwa, pendidikan agama Islam bertujuan untuk meningkatkan keimanan, pemahaman, penghayatan dan pengamalan peserta didik tentang agama Islam, sehingga menjadi manusia muslim yang beriman dan bertakwa kepada Allah swt serta berakhlak mulia dalam kehidupan pribadi, bermasyarakat, berbangsa dan bernegara. ${ }^{1}$

Dalam konsep Islam, iman merupakan potensi rohani yang harus diaktualisasikan dalam bentuk amal saleh, sehingga menghasilkan prestasi rohani yang disebut takwa. Amal saleh itu menyangkut keserasian dan keselarasan hubungan manusia dengan Allah dan hubungan manusia dengan

\footnotetext{
${ }^{1}$ Muhaimin, Paradigma Pendidikan Islam: Upaya Mengefektifkan Pendidikan Agama Islam di Sekolah (Bandung: Remaja Rosdakarya, 2001), hlm. 78.
} 
dirinya yang membentuk kesalehan pribadi; hubungan manusia dengan sesamanya membentuk kesalehan sosial (solidaritas sosial), dan hubungan manusia dengan alam membentuk kesalehan terhadap alam sekitar.

Untuk mewujudkan harapan tersebut, maka dalam pembelajaran PAI proses yang dilalui dan dialami siswa seharusnya dimulai dari tahapan kognisi, yakni pengetahuan dan pemahaman siswa terhadap ajaran dan nilai-nilai yang terkandung dalam ajaran Islam, untuk selanjutnya menuju ke tahapan afeksi, yakni terjadinya proses internalisasi ajaran dan nilai agama ke dalam diri siswa, dalam arti menghayati dan meyakininya. Tahapan afeksi ini terkait erat dengan kognisi, dalam arti penghayatan dan keyakinan siswa menjadi kokoh jika dilandasi oleh pengetahuan dan pemahamannya terhadap ajaran dan nilai agama Islam. Melalui tahapan afeksi tersebut diharapkan dapat tumbuh motivasi dalam diri siswa dan tergerak untuk mengamalkan dan menaati ajaran Islam (tahapan psikomotorik) yang telah diinternalisasikan dalam dirinya. Dengan demikian akan terbentuk manusia muslim yang beriman, bertakwa dan berakhlak mulia.

Namun pada kenyataannya, pelaksanaan pembelajaran yang telah berjalan selama ini lebih ditujukan kepada perkembangan aspek kognitif/intelektual peserta didik, sementara aspek sikap dan tingkah laku kurang mendapat perhatian serius. Dengan kata lain, peserta didik hanya dituntut menguasai mata pelajaran pendidikan agama Islam tanpa diberi kesempatan untuk melakukan penghayatan/perenungan sehingga mereka benarbenar meyakininya dan teraktualisasi dalam tindakan/perbuatan. Hal ini menyebabkan agama hanya sampai pada tataran pengetahuan saja, sehingga tidak terlihat dalam pembentukan sikap dan tingkah laku yang sesuai dengan ajaran agama. Padahal agama Islam itu harus dipahami, diyakini dan diamalkan dalam kehidupan sehari-hari.

Berdasarkan pengalaman peneliti mengamati kegiatan pembelajaran pendidikan agama di sekolah, baik pada tingkat sekolah dasar, maupun pada tingkat lanjutan bahkan sampai perguruan tinggi, pembelajaran yang dilakukan guru/dosen di kelas, masih berorientasi kognitif. Sebagai indikator bahwa pembelajaran PAI terfokus pada intelektual/kognitif adalah masih banyaknya siswa/mahasiswa yang mengetahui ajaran agama, tetapi perilakunya tidak relevan dengan nilai-nilai ajaran agama yang diketahuinya. Mengapa pembelajaran ini masih lebih banyak terkonsentrasi pada aspek kognitif semata 
dari pada pertumbuhan kesadaran akan nilai-nilai agama, dan mengabaikan pembinaan aspek afektif dan konatif-volutif, ternyata ketika peneliti melakukan dialog dengan guru-guru yang mengajarkan bidang studi PAI di SMA N 3 Padangsidimpuan, mereka mengatakan sulit untuk mendesain kegiatan, merumuskan tujuan pembelajaran dan mengevaluasi pembelajaran yang berorientasi pada afektif.

Begitu pula ketika peneliti melakukan pengamatan awal di SMA N 3 Padangsidimpuan, selama tiga kali pertemuan sebelum diterapkan strategi reflektif dan transinternal, teridentifikasi bahwa penyajian materi masih dominan menekankan pada aspek kognitif, artinya peserta didik lebih dituntut untuk menguasai materi, belum terlihat upaya menumbuhkan kesadaran untuk menjalankan ajaran agama, pertanyaan yang diajukan belum mengarah pada upaya perenungan dan pengkajian untuk menumbuhkan kesadaran akan nilainilai tersebut, sehingga materi pembelajaran kurang berkembang.

Berdasarkan fenomena yang ada, maka perlu dilakukan terobosanterobosan, perbaikan-perbaikan, dalam rangka mewujudkan cita-cita ideal tujuan pendidikan agama sebagaimana telah dijelaskan pada pasal sebelumnya. Untuk itu peneliti ingin mencoba beberapa langkah yang akan dikembangkan dalam pembelajaran PAI ini melalui strategi pembelajaran afektif, sehingga kegiatan pembelajaran yang masih lebih banyak terfokus pada aspek kognitif dapat diubah atau diperbaiki.

Di antara strategi pembelajaran afektif tersebut adalah strategi reflektif dan transinternal, strategi pembelajaran afektif ini memang berbeda dengan strategi pembelajaran kognitif dan psikomotorik. Afektif berhubungan dengan nilai yang sulit diukur, karena menyangkut kesadaran seseorang yang tumbuh dari dalam. Dalam batas tertentu memang sikap (afeksi) dapat muncul dalam tingkah laku, akan tetapi penilaiannya untuk sampai pada kesimpulan yang bisa dipertanggungjawabkan membutuhkan ketelitian dan observasi yang terus menerus, dan hal ini tidaklah mudah untuk dilakukan, apalagi menilai perubahan sikap sebagai akibat dari proses pembelajaran yang dilakukan guru di sekolah. Namun demikian peneliti mencoba menawarkan sebuah penelitian tindakan kelas dengan judul: "Strategi Reflektif dan Transinternal Sebagai Upaya Menumbuhkan Penghayatan Siswa dalam Pembelajaran PAI (Penelitian Tindakan Kelas Pada Siswa SMA N 3 Padangsidimpuan)." 
Berdasarkan latar belakang masalah yang telah diuraikan di atas, maka yang menjadi masalah dalam penelitian ini adalah: "Apakah strategi reflektif dan transinternal dapat menumbuhkan penghayatan siswa terhadap pembelajaran PAI yang terwujud dalam sikap dan perilaku". Berasarkan rumusan masalah tersebut, maka penelitian ini bertujuan untuk menumbuhkan penghayatan siswa dalam pembelajaran PAI yang terwujud dalam sikap dan perilaku melalui penerapan strategi reflektif dan transinternal.

\section{TINJAUAN PUSTAKA}

\section{Konsep Strategi reflektif}

Strategi reflektif adalah suatu strategi pembelajaran nilai yang dilakukan dengan jalan mondar mandir antara menggunakan pendekatan teoretik ke pendekatan empirik, atau mondar mandir antara pendekatan deduktif dan induktif. ${ }^{2}$ Strategi tersebut relevan dengan tuntutan perkembangan berpikir peserta didik dan tujuan pembelajaran nilai untuk menumbuhkembangkan kesadaran rasional dan keluasan wawasan terhadap nilai tersebut. ${ }^{3}$ Hal ini sejalan dengan kesimpulan Gulo:

a. Pengembangan domain afektif pada nilai tidak bisa dipisahkan dari aspek kognitif dan psikomotorik;

b. Masalah nilai adalah masalah emosional dan karena itu dapat berubah, berkembang, sehingga bisa dibina;

c. Perkembangan nilai dan moral tidak terjadi sekaligus, tetapi melalui tahap tertentu. ${ }^{4}$

Oleh karena itu, dalam menjalankan strategi ini digunakan pendekatan rasional, yakni usaha untuk memberikan peranan kepada rasio (akal) dalam memahami dan menerima kebenaran ajaran agama. Seterusnya pendekatan emosional, yakni usaha untuk menggugah perasaan dan emosi peserta didik dalam meyakini, memahami dan menghayati ajaran Islam serta menumbuhkan motivasi agar peserta didik ikhlas mengamalkan ajaran agamanya.

\section{Konsep Strategi Transinternal}

Pembelajaran nilai dengan menggunakan strategi transinternal merupakan cara untuk membelajarkan nilai dengan jalan melakukan

\footnotetext{
${ }^{2}$ Noeng Muhadjir, Ilmu Pendidikan dan Perubahan Sosial (Yogyakarta: Rake Sarasin, 1987), hlm. 124.

${ }^{3}$ M. Chabib Thaha, Pendidikan Nilai Kemanusiaan dan Ketuhanan (Yogyakarta: IAIN Sunan Kalijaga, 1988), hlm. 56.

${ }^{4}$ W. Gulo, Strategi Belajar Mengajar (Jakarta: Grasindo, 2002). hlm. 127.
} 
94 | TAZKIR: Jurnal Penelitian Ilmu-ilmu Sosial dan Keislaman

Vol. 02 No. 2 Desember 2016

transformasi nilai, dilanjutkan dengan transaksi dan transinternalisasi. Dalam hal ini, guru dan peserta didik sama-sama terlibat dalam proses komunikasi aktif, yang tidak hanya melibatkan komunikasi verbal dan fisik, tetapi melibatkan komunikasi batin (kepribadian) antara keduanya. Strategi inilah yang sesuai untuk menanamkan nilai-nilai ajaran agama. ${ }^{5}$

Jika dalam strategi reflektif hanya terbatas pada pemilihan nilai dengan disertai wawasan yang cukup luas dan mendalam terhadap makna nilai tersebut, maka pada strategi transinternal ini sasarannya sampai kepada tahap pemilikan nilai yang menyatu dalam pribadi siswa, atau sampai pada taraf karakteristik atau mewatak. ${ }^{6}$

\section{Pembelajaran Pendidikan Agama Islam}

Pembelajaran PAI sebenarnya lebih banyak menonjolkan aspek nilai, baik nilai ketuhanan maupun kemanusiaan, yang hendak ditanamkan dan ditumbuhkembangkan ke dalam diri peserta didik hingga dapat melekat pada dirinya dan menjadi kepribadiannya.

Dalam mata pelajaran PAI ketiga pembidangan kognitif, afektif dan psikomotorik saling berkaitan dan ketiganya harus seimbang. Sebab pengetahuan tentang konsep-konsep dalam Islam tidak hanya penting dilihat dari sudut sistem pengetahuan, tetapi juga penting dilihat dari segi sikap dan pengamalan. Pemahaman dan sikap yang benar tentang konsep Islam dapat membantu benarnya pengamalan ajaran Islam.

Menurut Ahmad Tafsir inti pendidikan agama Islam ialah penanaman iman. Jika kita membicarakan bagaimana cara mengajarkan agama Islam, maka inti pembicaraan kita adalah bagaimana menjadikan peserta didik kita orang yang beriman. Iman merupakan sikap beragama, inti beragama adalah masalah sikap, yaitu menerima atau menolak, taat atau ingkar. ${ }^{7}$

Jika kita ingin membina iman, maka kita mesti mengetahui lebih dahulu dimana tempat iman. Dalam Al-Quran Surat Al-Hujurat ayat 14 menjelaskan bahwa iman itu tempatnya di hati (qalb). Seperti dikatakan Al-Ghazali dalam Khoiran Rosyadi bahwa guru selalu berurusan dengan hati dan jiwa manusia. ${ }^{8}$ Jika demikian, seharusnya pembelajaran keimanan harus melibatkan perasaan

\footnotetext{
${ }^{5}$ M. Chabib Thaha, Pendidikan Nilai...., hlm. 58.

${ }^{6}$ Muhaimin, Paradigma Pendidikan..... hlm. 178.

${ }^{7}$ Ahmad Tafsir, Metodologi Pengajaran Agama Islam (Bandung: Remaja Rosdakarya, 2004), hlm. 124.

${ }^{8}$ Khoiran Rosyadi, Pendidikan Profetik (Yogyakarta: Pustaka Pelajar, 2004), hlm. 175.
} 
dan emosi peserta didik agar hatinya tergugah dan dapat menerima keimanan tersebut dengan kesadarannya sendiri.

Kesadaran itu dimulai dari kesadaran etis atau moral, yaitu kesadaran tentang diri sendiri dalam melihat masalah tersebut baik atau buruk, benar atau salah. Manusia sebagai makhluk etis, memiliki kesadaran etis yang tumbuh perlahan-lahan sejalan dengan proses pertumbuhannya. ${ }^{9}$ Berdasarkan pemikiran ini, dipahami bahwa pada dasarnya peserta didik telah memiliki potensi etis atau moral, namun dikarenakan banyaknya pengaruh-pengaruh negatif yang ada dilingkungannya, menyebabkan potensi ini tidak tumbuh dan berkembang. Oleh karena itu guru PAI harus berupaya untuk menumbuhkembangkan potensi itu kembali melalui kegiatan pembelajaran yang dilaksanakannya.

Dalam kegiatan pembelajaran PAI, ada beberapa dimensi yang hendak ditingkatkan dan dituju, yaitu: a. dimensi keimanan, b. dimensi pemahaman atau penalaran (intelektual) serta keilmuan, c. dimensi penghayatan atau pengalaman batin yang dirasakan peserta didik, d. dimensi pengamalan. Sementara itu Muhammad Quthb dalam Khoiran Rosyadi menjelaskan bahwa tujuan pendidikan Islam adalah manusia yang bertakwa, yaitu manusia yang senantiasa menuruti ajaran Allah. ${ }^{10}$

Dengan melakukan refleksi atau perenungan yang mendalam tentang dirinya sendiri dengan mengkaji segala nikmat dan karunia Allah terhadap dirinya kemudian merenungkan tentang alam semesta dengan segala isinya. Apabila semua ini dipikirkan dan direnungkan, maka diharapkan peserta didik merasa akan semakin dekat kepada Allah. Selanjutnya dengan melihat berbagai peristiwa/bencana dan membayangkan bagaimana peristiwa pada hari akhirat/kiamat, diharapkan dapat menambah kuat keyakinan mereka terhadap hari kiamat. Apabila refleksi ini sering dilakukan peserta didik, maka akan terjadi perubahan dalam diri mereka.

Selain itu dengan strategi transinternal, dimana guru merupakan figur sentral yang menjadi contoh/teladan bagi peserta didik untuk menyerap nilainilai ajaran agama yang ada pada diri guru tersebut, merupakan strategi yang cukup tepat untuk mengajarkan etika atau akhlak kepada peserta didiknya. Melalui tindakan kelas ini diharapkan terjadi perubahan, perbaikan atau 111.

\footnotetext{
${ }^{9}$ Burhanuddin Salam, Filsafat Manusia: Antropologi Metafisika (Jakarta: Bina Aksara, 1988), hlm.

${ }^{10}$ Khoiran Rosyadi, Pendidikan Profetik, hlm. 165.
} 
96 | TAZKIR: Jurnal Penelitian Ilmu-ilmu Sosial dan Keislaman

Vol. 02 No. 2 Desember 2016

peningkatan kualitas pembelajaran, yang pada gilirannya akan meningkatkan kualitas pengamalan agama siswa.

\section{Penelitian Terdahulu}

Penelitian tindakan kelas dapat dilakukan secara efektif oleh setiap guru/dosen untuk meningkatkan kualitas pembelajaran, tanpa harus meninggalkan tugas mengajarnya. Oleh karena itu akhir-akhir ini penelitian tindakan kelas mendapat perhatian di kalangan dunia pendidikan khususnya guru/dosen. Hal ini terbukti dari banyaknya penelitian tindakan kelas yang dilakukan guru/dosen mulai dari tingkat SD sampai Perguruan Tinggi. Dari beberapa penelitian tersebut, penulis akan menyajikan penelitian yang relevan dengan judul penelitian ini, yaitu:

1. Efektivitas Model Pembelajaran Reflektif dengan Pendekatan Realistik Berbasis Keislaman Terhadap Karakter Tanggungjawab Siswa Kelas VII MTs N Sumberagung. Hasil penelitian menunjukkan bahwa uji U hasil post- angket memiliki nilai signifikan 0,805 yang berarti rata-rata skor postangket kelas eksperimen sama dengan kelas kontrol. Hal tersebut menunjukkan bahwa model pembelajaran reflektif dengan pendekatan realistik berbasis keislaman tidak lebih efektif dibandingkan dengan pembelajaran yang menerapkan model konvensional terhadap karakter tanggung jawab siswa kelas VII MTs Negeri Sumberagung tahun ajaran 2012/2013. ${ }^{11}$

2. Pengaruh Penerapan Model Pembelajaran Reflektif Terhadap Hasil Belajar Siswa Kelas X MAN Malang 1 Tahun ajaran 2012/2013. Hasil analisis menunjukkan bahwa model pembelajaran reflektif tidak memberikan pengaruh secara signifikan terhadap hasil belajar siswa. Namun,dilihat dari nilai rata-rata kelas dan ketuntasan belajar, siswa kelas eksperimen memiliki nilai rata-rata dan ketuntasan belajar lebih tinggi dari kelas control. ${ }^{12}$

3. Model Konsiderasi Pembelajaran PAI Materi Tasamuh/Toleransi di SMP Kelas IX dalam Internalisasi Nilai-nilai Akhlak Mulia. Hasil penelitian ini menyimpulkan bahwa model konsiderasi merupakan salah satu model

\footnotetext{
${ }^{11}$ Ihas Mufliha, "Efektivitas Model Pembelajaran Reflektif dengan Pendekatan Realistik Berbasis Keislaman Terhadap Karakter Tanggungjawab Siswa Kelas VII MTs N Sumberagung”. (Thesis, Yogyakarta, 2013)

12 Izzatul Lailiyah, "Pengaruh Penerapan Model Pembelajaran Reflektif Terhadap Hasil Belajar Siswa Kelas X MAN Malang 1 Tahun ajaran 2012/2013” (Thesis, Malang, 2013)
} 
pembelajaran afektif yang memiliki tujuan, fungsi dan kontribusi dalam membentuk akhlak mulia. Model konsiderasi menghasilkan strategi dalam membentuk akhlak mulia yaitu strategi tradisional, strategi bebas, strategi reflektif, dan strategi transinternal. ${ }^{13}$

Berdasarkan penelaahan terhadap hasil penelitian di atas, peneliti mencoba melakukan penelitian tindakan kelas dengan memfokuskan masalah pada pengembangan strategi pembelajaran PAI yang berorientasi afektif melalui strategi reflektif dan strategi transinternal dengan tujuan menumbuhkembangkan kesadaran rasional dan emosional siswa terhadap ajaran, doktrin atau nilai-nilai Islam sehingga termotivasi dan ikhlas dalam menjalankan ajaran tersebut.

\section{METODOLOGI PENELITIAN}

Kegiatan penelitian ini dilaksanakan di SMA N 3, beralamat di jalan Printis Kemerdekaan nomor 63 Padangsidimpuan. Waktu penelitian dilakukan sejak bulan Maret 2013 s/d Oktober 2013, dengan melakukan berbagai tahapan mulai dari melakukan identifikasi dan membuat formulasi masalah, menyusun proposal/perencanaan, mengumpulkan data, menganalisis data sampai dengan membuat laporan. Subjek penelitian ini adalah siswa kelas X 5 SMA N 3 Padangsidimpuan sebagai siswa kelas unggulan terpadu. Siswa kelas X 5 yang mengikuti mata pelajaran Pendidikan Agama Islam berjumlah 39 orang yang keseluruhannya beragama Islam, 17 laki-laki dan 22 perempuan.

Metode yang digunakan dalam penelitian ini adalah metode classroom action research atau penelitian tindakan kelas dengan pendekatan yang digunakan adalah pendekatan kualitatif. Alat pengumpul data yang digunakan dalam penelitian ini adalah: Observasi Terstruktur dan Wawancara. Analisis melalui tahapan-tahapan siklus yang dilaksanakan pada saat penelitian, sedangkan analisis data tentang sikap siswa dalam pembelajaran reflektif dan transinternal dilakukan dengan membandingkan sebelum dilakukan tindakan kelas siklus I, dan siklus II. Selain mendeskripsikan hasil analisis data secara naratif, peneliti juga menggunakan bentuk analisis statistik deskriptif dengan menghitung (mentally) sikap siswa yang dikumpulkan melalui observasi terstruktur dan menyajikannya dalam bentuk tabulasi frekuensi.

\footnotetext{
${ }^{13}$ Ruhyana, "Model Konsiderasi Pembelajaran PAI Materi Tasamuh/Toleransi di SMP Kelas IX dalam Internalisasi Nilai-nilai Akhlak Mulia" dalam Jurnal Pendidikan Islam Indonesia, Oktober 2011.
} 
98 | TAZKIR: Jurnal Penelitian Ilmu-ilmu Sosial dan Keislaman

Vol. 02 No. 2 Desember 2016

\section{HASIL PENELITIAN DAN PEMBAHASAN}

Selain pemaparan secara naratif mengenai tindakan yang dilakukan dalam strategi reflektif maupun transinternal peneliti juga akan menjelaskan perkembangan sikap mental, kesadaran rasional, keluasan wawasan, perasaan dan penghayatan siswa terhadap nilai-nilai ajaran Islam dalam bentuk tabulasi persentase, sebagaimana terlihat pada table di bawah ini:

Tabel 1

Sikap, Kesadaran Rasional dan Keluasan Wawasan Siswa pada Siklus I dan II Strategi Reflektif

\begin{tabular}{|c|c|c|c|c|c|}
\hline No. & Aspek Penelitian & $\begin{array}{l}\text { Siklus } \\
\text { I }\end{array}$ & $\begin{array}{l}\text { Siklus } \\
\text { II }\end{array}$ & $\begin{array}{l}\text { Pe- } \\
\text { ning- } \\
\text { katan }\end{array}$ & Refleksi \\
\hline 1 & $\begin{array}{l}\text { Memberikan perhatian } \\
\text { penuh dan berkemauan } \\
\text { untuk mempelajari, } \\
\text { menganalisis } \\
\text { mengamati dan } \\
\text { agama yang sedajaran } \\
\text { dipelajari. }\end{array}$ & $24 \%$ & $36 \%$ & $12 \%$ & $\begin{array}{l}\text { Mulai terlihat } \\
\text { kesadaran akan } \\
\text { nilai/kepentingan } \\
\text { agama bagi mereka. }\end{array}$ \\
\hline 2 & $\begin{array}{l}\text { Memberikan respon dan } \\
\text { antusias dalam } \\
\text { merenungkan pelajaran } \\
\text { agama. }\end{array}$ & $26 \%$ & $36 \%$ & $10 \%$ & $\begin{array}{l}\text { Mulai menyadari } \\
\text { makna tafakur yang } \\
\text { dilakukannya. }\end{array}$ \\
\hline 3 & $\begin{array}{l}\text { Memberikan penilaian } \\
\text { terhadap } \\
\text { perenungannya. }\end{array}$ & $25 \%$ & $40 \%$ & $15 \%$ & $\begin{array}{l}\text { Mulai } \quad \text { berani } \\
\text { mengungkapkan } \\
\text { secara jujur tentang } \\
\text { kesalahan yang } \\
\text { pernah dilakukannya. }\end{array}$ \\
\hline 4 & $\begin{array}{l}\text { Mengambil keputusan } \\
\text { untuk memilih dan } \\
\text { menata suatu sistem } \\
\text { nilai ke dalam dirinya. }\end{array}$ & $24 \%$ & $36 \%$ & $12 \%$ & $\begin{array}{lr}\text { Perlu diarahkan } \\
\text { dalam mengambil } \\
\text { keputusan. }\end{array}$ \\
\hline 5 & $\begin{array}{l}\text { Menyatakan kesediaan } \\
\text { dan berusaha } \\
\text { mengubah serta } \\
\text { memperbaiki tingkah } \\
\text { laku sehingga sesuai } \\
\text { dengan ajaran Islam. }\end{array}$ & $21 \%$ & $38 \%$ & $17 \%$ & $\begin{array}{lr}\text { Masih } & \text { perlu } \\
\text { dimotivasi } & \text { untuk } \\
\text { melakukan } & \\
\text { perubahan ke } & \text { arah } \\
\text { yang lebih baik. } & \end{array}$ \\
\hline
\end{tabular}




\begin{tabular}{|c|c|c|c|c|c|}
\hline No. & Aspek Penelitian & $\begin{array}{l}\text { Siklus } \\
\text { I }\end{array}$ & $\begin{array}{l}\text { Siklus } \\
\text { II }\end{array}$ & $\begin{array}{l}\text { Pe- } \\
\text { ning- } \\
\text { katan }\end{array}$ & Refleksi \\
\hline \multirow[t]{2}{*}{6} & Menunjukkan & & & & Perlu pemberian \\
\hline & $\begin{array}{l}\text { perubahan tingkah laku } \\
\text { dan perbuatan terpuji. }\end{array}$ & $27 \%$ & $35 \%$ & $8 \%$ & $\begin{array}{lr}\text { pengalaman dan } & \text { dantuk } \\
\text { pembiasaan } & \text { untur } \\
\text { menanamkan } & \text { nilai- } \\
\text { nilai agama. } & \\
\end{array}$ \\
\hline 7 & $\begin{array}{l}\text { Mempengaruhi dan } \\
\text { mengajak teman untuk } \\
\text { melakukan ibadah dan } \\
\text { kebajikan. }\end{array}$ & $21 \%$ & $32 \%$ & $11 \%$ & $\begin{array}{lr}\text { Perlu } & \text { dimotivasi } \\
\text { untuk } & \text { berbagi } \\
\text { pengalaman batin. }\end{array}$ \\
\hline 8 & $\begin{array}{l}\text { Membuktikan } \\
\text { peningkatan dengan } \\
\text { melakukan shalat sunat } \\
\text { sebelum dan sesudah } \\
\text { zuhur. }\end{array}$ & $23 \%$ & $34 \%$ & $11 \%$ & $\begin{array}{ll}\text { Perlu } & \text { diberi } \\
\text { kesempatan } & \text { untuk } \\
\text { senantiasa } & \\
\text { mengamalkan } & \text { ajaran } \\
\text { agamanya. } & \end{array}$ \\
\hline 9 & $\begin{array}{l}\text { Membentuk pendapat } \\
\text { berdasarkan beberapa } \\
\text { pilihan tentang nilai } \\
\text { yang ada. }\end{array}$ & $28 \%$ & $37 \%$ & $9 \%$ & $\begin{array}{l}\text { Perlu dibiasakan } \\
\text { untuk } \\
\text { mengemukakan } \\
\text { argumentasi }\end{array}$ \\
\hline 10 & $\begin{array}{l}\text { Menyatakan sikap serta } \\
\text { keyakinannya terhadap } \\
\text { ayat yang dibahas } \\
\text { berdasarkan analisis } \\
\text { secara tekstual dan } \\
\text { kontekstual. }\end{array}$ & $21 \%$ & $40 \%$ & $19 \%$ & $\begin{array}{l}\text { Masih perlu banyak } \\
\text { membaca dan dilatih } \\
\text { melakukan analisis } \\
\text { konsep-konsep dan } \\
\text { realita yang ada pada } \\
\text { tataran empiris. }\end{array}$ \\
\hline 11 & $\begin{array}{l}\text { Memberikan tanggapan } \\
\text { dengan tepat dan } \\
\text { memiliki argumentasi } \\
\text { serta memberikan bukti } \\
\text { berupa fakta dan data } \\
\text { yang akurat }\end{array}$ & $21 \%$ & $33 \%$ & $12 \%$ & $\begin{array}{l}\text { Masih perlu banyak } \\
\text { membaca dan dilatih } \\
\text { mengajukan pendapat } \\
\text { berdasarkan } \\
\text { argumentasi yang } \\
\text { tepat. }\end{array}$ \\
\hline
\end{tabular}


100 | TAZKIR: Jurnal Penelitian Ilmu-ilmu Sosial dan Keislaman

Vol. 02 No. 2 Desember 2016

Tabel 2

Perasaan dan Penghayatan Siswa terhadap Nilai-nilai Ajaran Islam pada Siklus I dan II Strategi Reflektif

\begin{tabular}{|c|c|c|c|c|c|}
\hline No. & Aspek Penelitian & $\begin{array}{c}\text { Siklus } \\
\text { I }\end{array}$ & $\begin{array}{l}\text { Siklus } \\
\text { II }\end{array}$ & $\begin{array}{c}\text { Pening } \\
\text { katan }\end{array}$ & Refleksi \\
\hline 1 & $\begin{array}{l}\text { Merasa tergugah } \\
\text { dengan adanya syair } \\
\text { yang bernafaskan Islam. }\end{array}$ & $38 \%$ & $54 \%$ & $16 \%$ & $\begin{array}{l}\text { Lebih mudah } \\
\text { tergugah perasaan } \\
\text { keagamaannya } \\
\text { dengan adanya } \\
\text { musik klasik yang } \\
\text { bernuansa Islami } \\
\text { pada pembelajaran } \\
\text { PAI }\end{array}$ \\
\hline 2 & $\begin{array}{l}\text { Menyatakan perasaan } \\
\text { kagum akan sifat-sifat } \\
\text { Allah. }\end{array}$ & $32 \%$ & $47 \%$ & $15 \%$ & $\begin{array}{ll}\text { Masih } & \text { perlu } \\
\text { dibiasakan } & \\
\text { menganalisa } & \\
\text { fenomena } & \text { alam } \\
\text { semesta. } & \\
\end{array}$ \\
\hline 3 & $\begin{array}{l}\text { Merasakan kerinduan } \\
\text { kepada Allah dan } \\
\text { Rasulnya. }\end{array}$ & $28 \%$ & $38 \%$ & $10 \%$ & $\begin{array}{l}\text { Masih perlu dilatih } \\
\text { dan ditumbuhkan } \\
\text { perasaan rindu } \\
\text { kepada Allah dan } \\
\text { RasulNya }\end{array}$ \\
\hline 4 & $\begin{array}{lr}\text { Pengakuan } & \text { penyesalan } \\
\text { dengan } & \text { penuh } \\
\text { kesadaran } & \text { terhadap } \\
\text { perbuatan kurang baik } & \text { kang telah dilakukan. }\end{array}$ & $32 \%$ & $49 \%$ & $17 \%$ & $\begin{array}{lr}\text { Sedikit lebih leluasa } \\
\text { dan } & \text { jujur } \\
\text { menyatakan } & \\
\text { perasannya } & \\
\text { terhadap } & \text { ajaran } \\
\text { agama. } & \\
\end{array}$ \\
\hline 5 & $\begin{array}{lr}\text { Menyatakan rasa } \\
\text { syukur akan nikmat dan } \\
\text { karunia yang telah } \\
\begin{array}{ll}\text { dianugerahkan } & \text { Allah } \\
\text { kepadanya. }\end{array}\end{array}$ & $27 \%$ & $46 \%$ & $19 \%$ & $\begin{array}{lr}\text { Masih } & \text { perlu dilatih } \\
\text { dan } & \text { dibiasakan } \\
\text { untuk } & \text { selalu } \\
\text { bersyukur. } & \end{array}$ \\
\hline 6 & $\begin{array}{l}\text { Menyadari akan tugas } \\
\text { yang } \\
\text { diamanahkan Allah }\end{array}$ & $27 \%$ & $44 \%$ & $17 \%$ & $\begin{array}{lr}\text { Masih perlu } & \text { diberi } \\
\text { bimbingan } & \text { dan } \\
\text { pengarahan } & \text { untuk } \\
\text { menyadari } & \text { siapa } \\
\text { dirinya. } & \end{array}$ \\
\hline 7 & $\begin{array}{l}\text { Muncul keinginan } \\
\text { untuk bertaubat dan }\end{array}$ & $26 \%$ & $41 \%$ & $15 \%$ & $\begin{array}{lr}\text { Masih } & \text { perlu } \\
\text { ditumbuhkan } & \text { rasa }\end{array}$ \\
\hline
\end{tabular}




\begin{tabular}{|c|c|c|c|c|c|}
\hline No. & Aspek Penelitian & $\begin{array}{c}\text { Siklus } \\
\text { I }\end{array}$ & $\begin{array}{l}\text { Siklus } \\
\text { II }\end{array}$ & $\begin{array}{l}\text { Pening } \\
\text { katan }\end{array}$ & Refleksi \\
\hline & $\begin{array}{l}\text { melakukan kebaikan- } \\
\text { kebaikan. }\end{array}$ & & & & $\begin{array}{ll}\text { ingin } & \text { berbuat } \\
\text { kebajikan. } & \end{array}$ \\
\hline 8 & $\begin{array}{l}\text { Menyatakan rasa } \\
\text { senang terhadap } \\
\text { kebajikan yang telah } \\
\text { dilakukannya }\end{array}$ & $36 \%$ & $51 \%$ & $15 \%$ & $\begin{array}{l}\text { Masih } \\
\text { dibiasakan } \\
\text { melakukan } \\
\text { kebajikan }\end{array}$ \\
\hline 9 & $\begin{array}{l}\text { Menemukan kepuasan } \\
\text { dalam melakukan } \\
\text { kebajikan }\end{array}$ & $31 \%$ & $43 \%$ & $12 \%$ & $\begin{array}{l}\text { Masih perlu dilatih } \\
\text { menghayati setiap } \\
\text { kegiatan keagamaan } \\
\text { yang dilakukan }\end{array}$ \\
\hline
\end{tabular}

Tabel 3

Sikap, Kesadaran Rasional dan Keluasan Wawasan Siswa pada Siklus I dan II Strategi Transinternal

\begin{tabular}{|c|c|c|c|c|c|}
\hline No. & Aspek Penelitian & $\begin{array}{c}\text { Siklus } \\
\text { I }\end{array}$ & $\begin{array}{c}\text { Siklus } \\
\text { II }\end{array}$ & $\begin{array}{l}\text { Pe- } \\
\text { ning } \\
\text { katan }\end{array}$ & Refleksi \\
\hline 1 & $\begin{array}{l}\text { Memberikan perhatian } \\
\text { penuh dan berkemauan } \\
\text { untuk mempelajari, } \\
\text { menganalisis } \\
\text { mengamati dan } \\
\text { agama yang sedajaran } \\
\text { dipelajari. }\end{array}$ & $51 \%$ & $75 \%$ & $24 \%$ & $\begin{array}{l}\text { Tumbuh kesadaran } \\
\text { akan } \\
\text { nilai/kepentingan } \\
\text { agama bagi mereka. }\end{array}$ \\
\hline 2 & $\begin{array}{l}\text { Memberikan respon dan } \\
\text { antusias dalam } \\
\text { mengikuti dialog antara } \\
\text { guru-siswa dan antar } \\
\text { siswa. }\end{array}$ & $49 \%$ & $71 \%$ & $22 \%$ & $\begin{array}{l}\text { Mulai termotivasi } \\
\text { untuk mendalami } \\
\text { pelajaran agama yang } \\
\text { diterimanya.. }\end{array}$ \\
\hline 3 & $\begin{array}{l}\text { Memberikan tanggapan } \\
\text { dengan tepat dan } \\
\text { memiliki argumentasi } \\
\text { serta memberikan bukti } \\
\text { berupa fakta dan data } \\
\text { yang akurat }\end{array}$ & $45 \%$ & $64 \%$ & $19 \%$ & $\begin{array}{l}\text { Sudah termotivasi } \\
\text { untuk membaca dan } \\
\text { berani mengajukan } \\
\text { pendapat berdasarkan } \\
\text { argumentasi yang } \\
\text { tepat. }\end{array}$ \\
\hline 4 & $\begin{array}{l}\text { Menjadikan guru } \\
\text { sebagai sumber nilai }\end{array}$ & $46 \%$ & $60 \%$ & $14 \%$ & $\begin{array}{lr}\begin{array}{l}\text { Keteladanan } \\
\text { menjadi }\end{array} & \text { guru } \\
\text { sumber }\end{array}$ \\
\hline
\end{tabular}


102 | TAZKIR: Jurnal Penelitian Ilmu-ilmu Sosial dan Keislaman

Vol. 02 No. 2 Desember 2016

\begin{tabular}{|c|c|c|c|c|c|}
\hline No. & Aspek Penelitian & $\begin{array}{l}\text { Siklus } \\
\text { I }\end{array}$ & $\begin{array}{l}\text { Siklus } \\
\text { II }\end{array}$ & $\begin{array}{l}\text { Pe- } \\
\text { ning } \\
\text { katan }\end{array}$ & Refleksi \\
\hline & & & & & $\begin{array}{l}\text { inspirasi siswa dalam } \\
\text { membentuk sikap. }\end{array}$ \\
\hline 5 & $\begin{array}{l}\text { Mengambil keputusan } \\
\text { untuk memilih dan } \\
\text { menata suatu sistem } \\
\text { nilai ke dalam dirinya. }\end{array}$ & $46 \%$ & $66 \%$ & $20 \%$ & $\begin{array}{l}\text { Mulai mampu } \\
\text { mengambil keputusan } \\
\text { dengan berbagai } \\
\text { pertimbangan. }\end{array}$ \\
\hline 6 & $\begin{array}{l}\text { Menyatakan kesediaan } \\
\text { dan berusaha } \\
\text { mengubah serta } \\
\text { memperbaiki tingkah } \\
\text { laku sehingga sesuai } \\
\text { dengan ajaran Islam. } \\
\end{array}$ & $55 \%$ & $72 \%$ & $17 \%$ & $\begin{array}{l}\text { Sudah termotivasi } \\
\text { untuk melakukan } \\
\text { perubahan ke arah } \\
\text { yang lebih baik. }\end{array}$ \\
\hline 7 & $\begin{array}{l}\text { Menunjukkan } \\
\text { perubahan tingkah laku } \\
\text { dan perbuatan terpuji. }\end{array}$ & $51 \%$ & $73 \%$ & $22 \%$ & $\begin{array}{l}\text { Sudah ada perubahan } \\
\text { sikap dan tingkah } \\
\text { laku kea rah yang } \\
\text { lebih baik. }\end{array}$ \\
\hline 8 & $\begin{array}{l}\text { Mempengaruhi dan } \\
\text { mengajak teman untuk } \\
\text { melakukan ibadah dan } \\
\text { kebajikan. }\end{array}$ & $44 \%$ & $63 \%$ & $19 \%$ & $\begin{array}{l}\text { Sudah ada kemajuan, } \\
\text { namun perlu diberi } \\
\text { dorongan } \\
\text { menerus. }\end{array}$ \\
\hline 9 & $\begin{array}{l}\text { Membuktikan } \\
\text { peningkatan dengan } \\
\text { melakukan shalat sunat } \\
\text { sebelum dan sesudah } \\
\text { zuhur. }\end{array}$ & $44 \%$ & $62 \%$ & $18 \%$ & $\begin{array}{l}\text { Sudah ada kemajuan, } \\
\text { namun masih perlu } \\
\text { keteladanan guru } \\
\text { serta pembiasaan. }\end{array}$ \\
\hline 10 & $\begin{array}{l}\text { Membentuk pendapat } \\
\text { berdasarkan beberapa } \\
\text { pilihan tentang nilai } \\
\text { yang ada. }\end{array}$ & $50 \%$ & $70 \%$ & $20 \%$ & $\begin{array}{l}\text { Mulai terbiasa } \\
\text { memberikan } \\
\text { pandangan terhadap } \\
\text { sesuatu nilai } \\
\text { berdasarkan berbagai } \\
\text { pertimbangan. }\end{array}$ \\
\hline 11 & $\begin{array}{l}\text { Menyatakan sikap serta } \\
\text { keyakinannya terhadap } \\
\text { ayat yang dibahas } \\
\text { berdasarkan analisis } \\
\text { secara tekstual dan } \\
\text { kontekstual. }\end{array}$ & $53 \%$ & $69 \%$ & $16 \%$ & $\begin{array}{l}\text { Sudah ada kemajuan, } \\
\text { namun masih perlu } \\
\text { dibiasakan untuk } \\
\text { menganalisis nilai- } \\
\text { nilai secara tekstual } \\
\text { dan kontekstual. }\end{array}$ \\
\hline
\end{tabular}


Tabel 4

Perasaan dan Penghayatan Siswa terhadap Nilai-nilai Ajaran Islam pada Siklus I dan II Strategi Transinternal

\begin{tabular}{|c|c|c|c|c|c|}
\hline No. & Aspek Penelitian & $\begin{array}{c}\text { Siklus } \\
\text { I }\end{array}$ & $\begin{array}{c}\text { Siklus } \\
\text { II }\end{array}$ & $\begin{array}{c}\text { Pening } \\
\text { katan }\end{array}$ & Refleksi \\
\hline 1 & $\begin{array}{lr}\text { Merasa } & \text { tergugah } \\
\text { dengan } & \text { adanya syair } \\
\text { yang } & \text { bernafaskan } \\
\text { Islam. } & \end{array}$ & $69 \%$ & $77 \%$ & $8 \%$ & $\begin{array}{l}\text { Dari wajah mereka } \\
\text { tersirat ketenangan } \\
\text { batin setelah } \\
\text { mendengarkan syair } \\
\text { Islam }\end{array}$ \\
\hline 2 & $\begin{array}{l}\text { Menyatakan perasaan } \\
\text { kagum akan sifat-sifat } \\
\text { Allah. }\end{array}$ & $58 \%$ & $72 \%$ & $14 \%$ & $\begin{array}{l}\text { Ada kemajuan, } \\
\text { namun masih harus } \\
\text { sering diberikan } \\
\text { contoh-contoh } \\
\text { konkrit. }\end{array}$ \\
\hline 3 & $\begin{array}{l}\text { Merasakan kerinduan } \\
\text { kepada Allah dan } \\
\text { Rasulnya. }\end{array}$ & $49 \%$ & $59 \%$ & $10 \%$ & $\begin{array}{l}\text { Mulai terlihat } \\
\text { kekhusukan dan } \\
\text { kesenduan di wajah } \\
\text { mereka menghayati } \\
\text { syair-syair Islam. }\end{array}$ \\
\hline 4 & $\begin{array}{l}\text { Pengakuan penyesalan } \\
\text { dengan penuh } \\
\text { kesadaran terhadap } \\
\text { perbuatan kurang baik } \\
\text { yang telah dilakukan. }\end{array}$ & $51 \%$ & $63 \%$ & $12 \%$ & $\begin{array}{l}\text { Sudah lebih leluasa } \\
\text { dan jujur } \\
\text { menyatakan } \\
\text { perasaan bersalah } \\
\text { karena melanggar } \\
\text { ajaran agama. }\end{array}$ \\
\hline 5 & $\begin{array}{l}\text { Menyatakan rasa } \\
\text { syukur akan nikmat } \\
\text { dan karunia yang telah } \\
\text { dianugerahkan Allah } \\
\text { kepadanya. }\end{array}$ & $68 \%$ & $83 \%$ & $15 \%$ & $\begin{array}{l}\text { Ada kesadaran yang } \\
\text { dalam untuk selalu } \\
\text { menyatakan rasa } \\
\text { syukur kepada } \\
\text { Allah. }\end{array}$ \\
\hline 6 & $\begin{array}{l}\text { Menyadari akan tugas } \\
\text { yang telah } \\
\text { diamanahkan Allah }\end{array}$ & $64 \%$ & $78 \%$ & $14 \%$ & $\begin{array}{lr}\text { Ada } & \text { kemajuan, } \\
\text { namun } & \text { perlu } \\
\text { dimotivasi } & \text { agar } \\
\text { senantiasa } & \\
\text { melaksanakan } & \text { tugas } \\
\text { yang } & \text { telah } \\
\text { diamanahkan } & \text { Allah. }\end{array}$ \\
\hline 7 & $\begin{array}{l}\text { Muncul keinginan } \\
\text { untuk bertaubat dan } \\
\text { melakukan kebaikan- }\end{array}$ & $59 \%$ & $74 \%$ & $15 \%$ & $\begin{array}{lr}\text { Ada } & \text { kemajuan, } \\
\text { namun } & \text { perlu } \\
\text { dimotivasi } & \text { agar }\end{array}$ \\
\hline
\end{tabular}


104 | TAZKIR: Jurnal Penelitian Ilmu-ilmu Sosial dan Keislaman

Vol. 02 No. 2 Desember 2016

\begin{tabular}{|c|c|c|c|c|c|}
\hline No. & Aspek Penelitian & $\begin{array}{c}\text { Siklus } \\
\text { I }\end{array}$ & $\begin{array}{l}\text { Siklus } \\
\text { II }\end{array}$ & $\begin{array}{l}\text { Pening } \\
\text { katan }\end{array}$ & Refleksi \\
\hline & kebaikan. & & & & $\begin{array}{l}\text { senantiasa } \\
\text { melaksanakan tugas } \\
\text { yang telah } \\
\text { diamanahkan Allah. }\end{array}$ \\
\hline 8 & $\begin{array}{l}\text { Menyatakan rasa } \\
\text { senang terhadap } \\
\text { kebajikan yang telah } \\
\text { dilakukannya }\end{array}$ & $65 \%$ & $80 \%$ & $15 \%$ & $\begin{array}{lr}\text { Tinggal diarahkan } \\
\text { saja agar mereka } \\
\text { ikhlas } \\
\text { melakukan }\end{array}$ \\
\hline 9 & $\begin{array}{l}\text { Menemukan kepuasan } \\
\text { dalam melakukan } \\
\text { kebajikan }\end{array}$ & $60 \%$ & $74 \%$ & $14 \%$ & $\begin{array}{l}\text { Ada peningkatan } \\
\text { dalam melakukan } \\
\text { penghayatan. }\end{array}$ \\
\hline
\end{tabular}

Jika dilihat dari strategi reflektif pada siklus I dan II jumlah siswa yang menerima dan memberi respon terhadap pelajaran agama cukup antusias begitu juga pada strategi transinternal siswa yang menerima dan memberi respon terhadap pelajaran agama meningkat. Hal ini menunjukkan bahwa kedua strategi tersebut dapat meningkatkan sikap mental, kesadaran rasional dan wawasan siswa dalam mengkaji dan mempelajari nilai-nilai ajaran Islam melalui pelajaran PAI. Selanjutnya dilihat dari keberanian mereka mengungkapkan perasaan dan kemauan mereka melakukan penghayatan terhadap ajaran agama yang dipelajari, sudah terlihat sejak dari siklus pertama kedua strategi ini diterapkan, mereka sudah mulai tergugah perasaan dan emosinya. Hal ini dikarenakan suasana religius yang diciptakan pada saat pembelajaran berlangsung.

Berdasarkan hasil wawancara peneliti kepada beberapa siswa kelas X 5 SMA N 3 Padangsidimpuan, peningkatan ini terjadi karena adanya rasa takut kepada Allah ketika diputar CD tentang bencana-bencana yang terjadi di dunia, dan juga rasa kagum akan kekuasaan Allah ketika mengamati pemutaran CD tentang ilmu pengetahuan baik yang berkenaan dengan penciptaan manusia maupun tentang ilmu tubuh manusia, serta penyajian pembelajaran PAI yang diiringi dengan alunan musik yang islami, sehingga perasaan mereka lebih 
tergugah dan kembali mengingat akan kebesaran Allah serta menyadari siapa dirinya dan kelalaian mereka selama ini. ${ }^{14}$

Menurut analisa peneliti adanya perubahan sikap mental, kesadaran rasional dan keluasan wawasan siswa, dikarenakan mereka mulai terbiasa dan terlatih untuk menyadari bahwa terdapat nilai yang sangat berharga pada bidang studi PAI, dan juga kepribadian guru yang menarik dan kharismatik, sehingga mereka mulai tertarik melakukan pengkajian baik secara tekstual maupun kontekstual, serta melakukan tafakur/perenungan terhadap alam sekitar dan juga terhadap diri mereka sendiri.

\section{PENUTUP}

Secara keseluruhan dari siklus I dan II penelitian tindakan kelas pada bidang studi Pendidikan Agama Islam baik strategi reflektif maupun transinternal telah berhasil menumbuhkan sikap mental, kesadaran rasional, keluasan wawasan, perasaan kagum akan kekuasaan Allah, empati terhadap sesama makhluk Allah, terdorong untuk merubah perilaku yang kurang baik dan meningkatkan perbuatan baik yang sudah dikerjakan selama ini.

${ }^{14}$ Anggi Sri Wulandari, Devi Eka Kartika, Mhd. Ali Habibi, Nanda Pratama, siswa-siswi kelas X SMA N 3 Padangsidimpuan, wawancara di sekolah, tanggal 06 Agustus 2013. 
106 | TAZKIR: Jurnal Penelitian Ilmu-ilmu Sosial dan Keislaman

Vol. 02 No. 2 Desember 2016

\section{DAFTAR RUJUKAN}

Ahmad Tafsir. Metodologi Pengajaran Agama Islam. Bandung: Remaja Rosdakarya, 2004.

Burhanuddin Salam. Filsafat Manusia: Antropologi Metafisika. Jakarta: Bina Aksara, 1988.

Ihas Mufliha. "Efektivitas Model Pembelajaran Reflektif dengan Pendekatan Realistik Berbasis Keislaman Terhadap Karakter Tanggungjawab Siswa Kelas VII MTs N Sumberagung". Thesis, Yogyakarta, 2013.

Izzatul Lailiyah. "Pengaruh Penerapan Model Pembelajaran Reflektif Terhadap Hasil Belajar Siswa Kelas X MAN Malang 1 Tahun ajaran 2012/2013". Thesis, Malang, 2013.

Khoiran Rosyadi. Pendidikan Profetik. Yogyakarta: Pustaka Pelajar, 2004.

M. Chabib Thaha. Pendidikan Nilai Kemanusiaan dan Ketuhanan. Yogyakarta: IAIN Sunan Kalijaga, 1988.

Muhaimin. Paradigma Pendidikan Islam: Upaya Mengefektifkan Pendidikan Agama Islam di Sekolah. Bandung: Remaja Rosdakarya, 2001.

Noeng Muhadjir. Ilmu Pendidikan dan Perubahan Sosial. Yogyakarta: Rake Sarasin, 1987.

Ruhyana. "Model Konsiderasi Pembelajaran PAI Materi Tasamuh/Toleransi di SMP Kelas IX dalam Internalisasi Nilai-nilai Akhlak Mulia" dalam Jurnal Pendidikan Islam Indonesia, Oktober 2011.

W. Gulo. Strategi Belajar Mengajar. Jakarta: Grasindo, 2002). hlm. 127. 